\title{
A GRAVITY SURVEY OF THE MELVILLE ISLAND ICE CAPS
}

\author{
By Allan Spector* \\ (University of Toronto, Toronto, Ontario, Canada)
}

\begin{abstract}
A gravity survey was made in June of 1963 of four ice caps on western Melville Island, Canadian Arctic Archipelago. Ice thicknesses were interpreted from Bouguer anomalies at $13^{8}$ stations. The regional gravity field of the area has a simple form and is associated with a uniform bedrock geology. Because of this, the interpretation of the gravity data was greatly simplified in comparison with the more usual glaciological problem. It was found that greatest ice thicknesses ranged from 30 to $50 \mathrm{~m}$., filling hidden valleys or depressions under the main ice-cap body. Ice-cap volumes ranged from 0.2 to $1 \cdot 0 \mathrm{~km} .^{3}$.

RÉsumé. Levé gravimétrique des calotles de glace de l'ille de Melville. Un levé gravimétrique a été effectué en juin 1963 des quatre calottes de glace de l'T̂le de Melville ouest, Archipel Arctique Canadien. L'épaisseur de la glace a été déduite des anomalies de Bouguer en ${ }_{1} 3^{8}$ stations. Le champ de gravité régional de la zone étudiée a une forme simple et il est associé à la géologie uniforme du socle rocheux. Ainsi, l'interprétation des mesures gravimétriques a été grandement simplifiée en comparaison des problèmes glaciologiques courants. Il a été trouvé que la plus grande épaisseur de glace se tenait entre 30 et $50 \mathrm{~m}$, remplissant des vallées et dépressions cachées sous l'ensemble de la calotte de glace. Les volumes des calottes de glace sont compris entre 0,2 et $1,0 \mathrm{~km}^{3}$.
\end{abstract}

Zusammenfassung. Schweremessungen auf den Eiskappen von Melville Island. Im Juni 1963 wurden Schweremessungen auf vier Eiskappen im westlichen Melville Island, Kanadischer Arktis-Archipel, durchgeführt. Die Eisdicke wurde aus Bouguer-Anomalien an $13^{8}$ Stationen abgeleitet. Das regionale Schwerkraftfeld hat einfache Form, herrührend vom gleichförmigen geologischen Aufbau des Untergrundes. Deshalb vereinfachte sich im Vergleich zu dem sonst vorliegenden glaziologischen Problem die Interpretation der Schwerkraftwerte weitgehend. Als grösste Eisdicken wurden Werte zwischen 30 und $50 \mathrm{~m}$ gefunden; sie treten auf über Tälern oder Vertiefungen, die sich unter der Hauptmasse der Eiskappen verbergen. Das Volumen der Eiskappen liegt zwischen 0,2 und $\mathrm{I}, \mathrm{o} \mathrm{km}^{3}$.

\section{The Gravity Survey}

The general location of the ice caps is shown in Figure I ; they are designated as "North", "West", "East" and "South" ice cap according to their relative positions. Approximately elliptical in shape, the ice caps lie on the dissected plateau which is the principal topographic form of west Melville Island. The ice caps range in area from ${ }_{5} 5$ to $55 \mathrm{~km}^{2}$ and lie at an average elevation of $55^{\circ} \mathrm{m}$.

The objectives of the gravity survey, performed in June 1963 , were to find the general form of the ice bodies and to determine the locations of greatest ice thickness, suitable for a future bore hole for glaciological and heat-flow studies. The survey was performed by the author, a member of the Dominion Observatory Gravity Division affiliated with the Polar Continental Shelf Project (P.C.S.P.).

During a nine-day period ${ }_{1} 3^{8}$ gravity stations were established and linked with the gravity control station network established by the Dominion Observatory in the Arctic Islands. Transportation was provided by a Bell $47 \mathrm{G}-2 \mathrm{~A}$ helicopter. Gravity measurements were made using a temperature-compensated Worden gravity meter which had a scale constant of $0.40718 \mathrm{mgal} /$ div. Geographical positions of most gravity stations were established by tellurometer traverse and triangulation. Elevations were determined by trigonometric levelling. The stations are separated by intervals of from 0.8 to $2.5 \mathrm{~km}$.

Values of gravity at each station were adjusted for the gravitational effects of varying latitude and elevation according to standard procedures (Dobrin, i 96o, p. 187-9o) to obtain the Bouguer gravity anomaly. The density of the underlying bedrock, important in carrying out the above reduction, was estimated from the average of 29 dry rock samples: $2 \cdot 30 \pm 0 \cdot 05$ g./cm. ${ }^{3}$. The Hammer terrain correction chart (Hammer, I939) was used in making correc-

* This material was presented to the University of Toronto in partial fulfilment of an M.A. degree. 


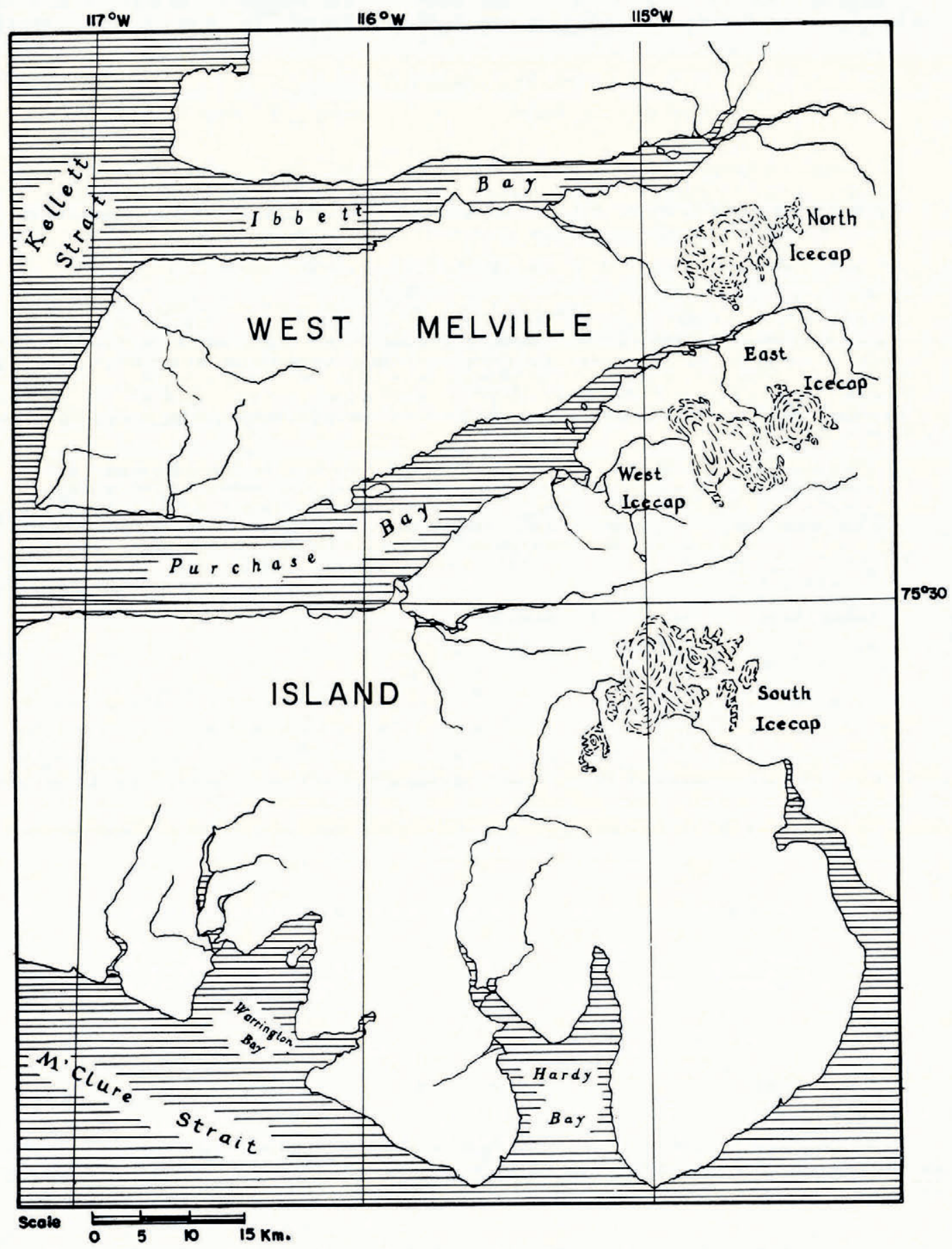

Fig. I. Location of the Melville Island ice caps 
tions for the gravity effect of topographic relief about each station to a radius of $18 \cdot 8 \mathrm{~km}$. The terrain effect was found to be usually less than 0.5 mgal however in a few cases, it was as high as $2 \cdot 5$ mgal.

\section{Interpretation of the Gravity Data}

Accumulations of ice occur at relatively high elevation, usually in mountainous terrain. Because of this the gravity data include significant contributions from effects in addition to the anomaly of a low-density ice body. The gravity effect of irregular topography can be so significant that without adequate topographic mapping in order to calculate the terrain effect, interpretation of the gravity data is severely limited in value. A more subtle difficulty is involved in separating the gravity effect of the ice body from the effect of density variations associated with a possibly complex underlying geology. Detailed geological information is always lacking and because of this, estimates of the "regional" gravity field arising from bedrock density variations, are quite conjectural. These and other difficulties are acknowledged by authors engaged in ice thickness interpretation; Littlewood (I952), Bull and Hardy (I956), Thiel and others (1957), Russell and others (r96o), Weber (r96r) and Hyndman (Koerner and others, 1963 , p. $71-72)$.

The underlying bedrock of this area consists of at least 2, $100 \mathrm{~m}$. of flat-lying sandstone of Devonian age, resting on at least 4,500 m. of older sediments of the Franklinian Geosyncline (Thorsteinsson and Tozer, I959). The "regional" anomaly for each ice cap was estimated from the Bouguer anomaly (including terrain correction) at stations established exterior to the ice caps. In all four cases, after the regional anomaly was contoured using this exterior data, it was observed that the gradient is small and almost linear: $0.6,0.5,0.4$ and $0.6 \mathrm{mgal} / \mathrm{km}$. in a south to south-east direction for the "North", "East", "West" and "South" ice caps respectively. A gravity survey of the Melville Island area (Spector, unpublished) consisting of stations separated at intervals of about ro $\mathrm{km}$., reveals that the gravity field of a large area including the ice-cap region is indeed slowly varying, confirming the estimate of the regional anomaly made in the ice-cap survey.

In Figure 2, the Bouguer anomaly (including terrain correction) at each gravity station is shown and the data are contoured at $0.5 \mathrm{mgal}$ intervals. Exceptionally low anomalies were observed at two stations on the extreme north-eastern and south-eastern parts of the "North" ice cap and also in the north-eastern part of the "South" ice cap. Contouring of the gravity data in the vicinity of these stations is fairly conjectural because of the lack of neighbouring stations. These anomalies can only be determined by a more detailed gravity survey.

Figure 3 shows the contoured residual anomaly pattern after the removal of the regional anomaly from the data. Over the major parts of the ice caps, the residual anomaly can be seen to be quite slowly varying. Inherent in this picture is the effect of the wide spacing of the data points achieving a smoothed representation of the actual gravity field.

The uniqueness of gravity interpretations is satisfied in glaciological problems because the upper surface of the "disturbing mass" is known and the problem is reduced to the mapping of a single interface, viz. the ice-bedrock contact. Because of the apparent smoothness of the residual anomaly in the greater portion of each ice cap, the following interpretational technique was chosen. The Bouguer formula,

$$
\Delta g=2 \pi G \Delta \rho t
$$

represents the gravity effect of a slab of ice having a thickness $t$, a density contrast with respect to underlying bedrock of $\Delta \rho$ and whose horizontal dimensions are very large in comparison to $t$. The ice density was assumed to be $0 \cdot 9^{\mathrm{I}} \mathrm{g} \cdot / \mathrm{cm} \cdot{ }^{3}$, resulting in a density contrast of $-\mathrm{I} \cdot 39$ g. $/ \mathrm{cm} .{ }^{3} \cdot G$ is the universal gravitational constant, $6 \cdot 668 \times \mathrm{IO}^{-8}$ in c.g.s. units. 


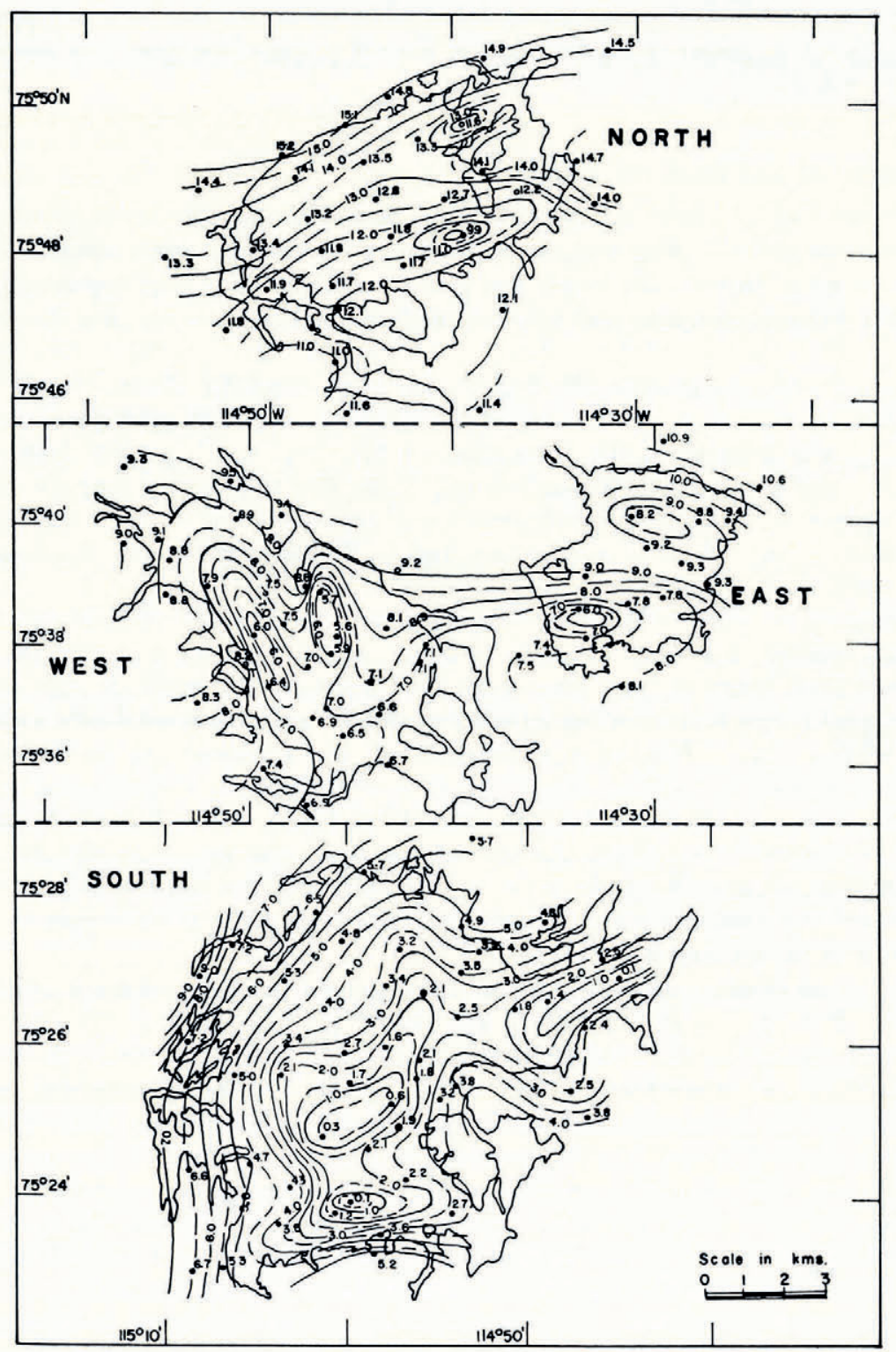

Fig. 2. Bouguer gravity maps of the ice caps, contour interval $0.5 \mathrm{mgal}$

Figure 4 illustrates the interpreted ice distribution. In all four ice caps, the ice body is characterized by two thick zones separated apparently by a bedrock hill. It is surprising that the thickness of ice in these zones is comparatively the same for all four ice caps, namely 30 to $50 \mathrm{~m}$. The ice-rock interface appears to be undulating. The exceptionally low gravity anomalies measured at stations at the north-eastern extremities of both the "North" and "South" ice caps imply the possibility that very thick ice may be found in narrow valleys emanating from the central part of the ice caps. The true nature of these valley ice zones awaits further investigation. 


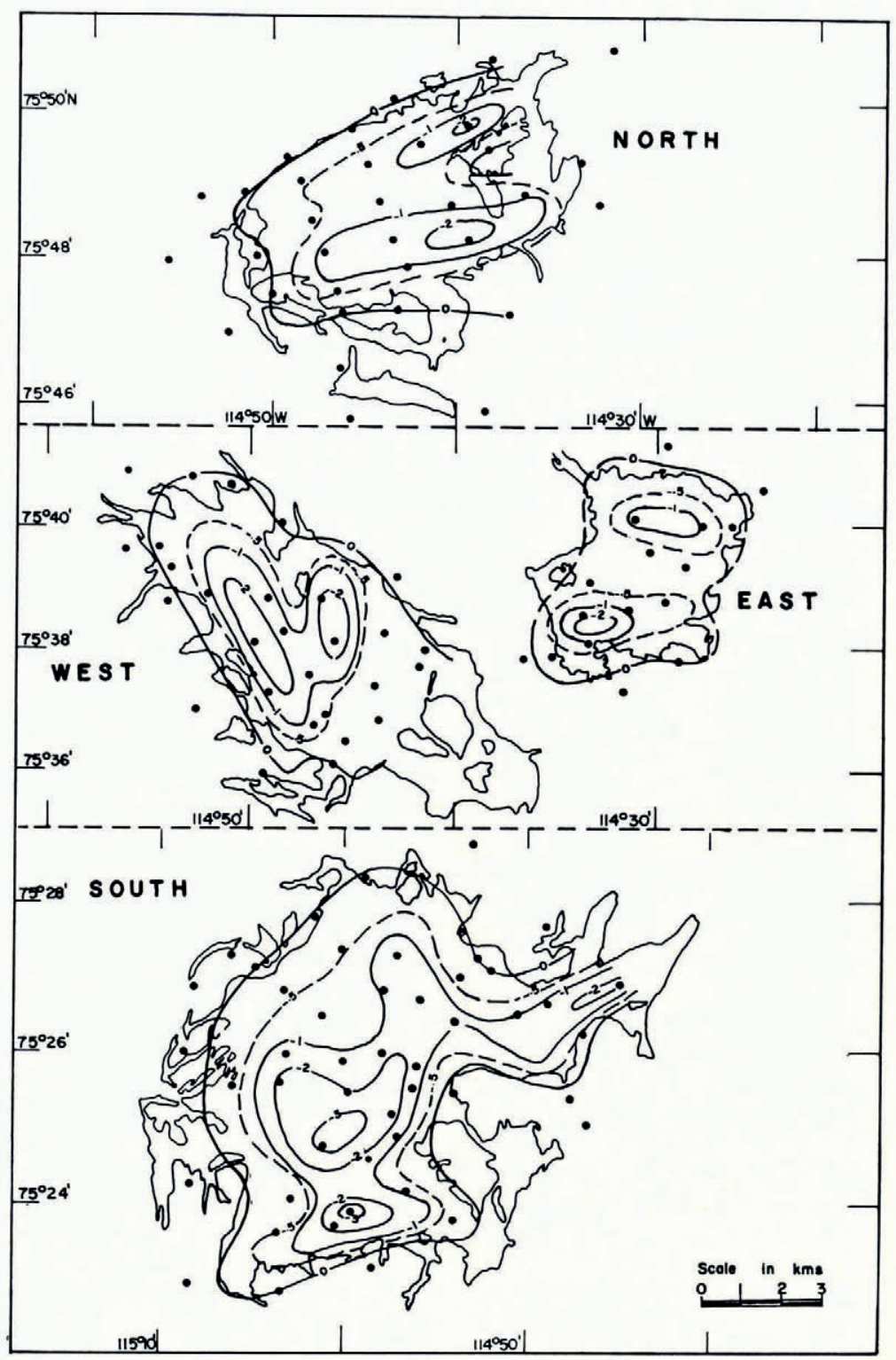

Fig. 3. Residual gravity maps of the ice caps, contour values in milligals

The volume of ice in an ice cap can be estimated by integrating numerically the gravity anomaly over the area of the observation plane (Hammer, 1945);

$$
\text { Volume }=\frac{\text { Mass deficit }}{\text { Density contrast }}=\frac{\mathrm{I}}{2 \pi G \Delta \rho} \iint \Delta g d a .
$$

The estimated volumes were found to be $0 \cdot 4,0 \cdot 4,0 \cdot 2$ and I $\cdot 0 \mathrm{~km} .{ }^{3}$ for the "North", "West", "East" and "South" ice caps respectively. 


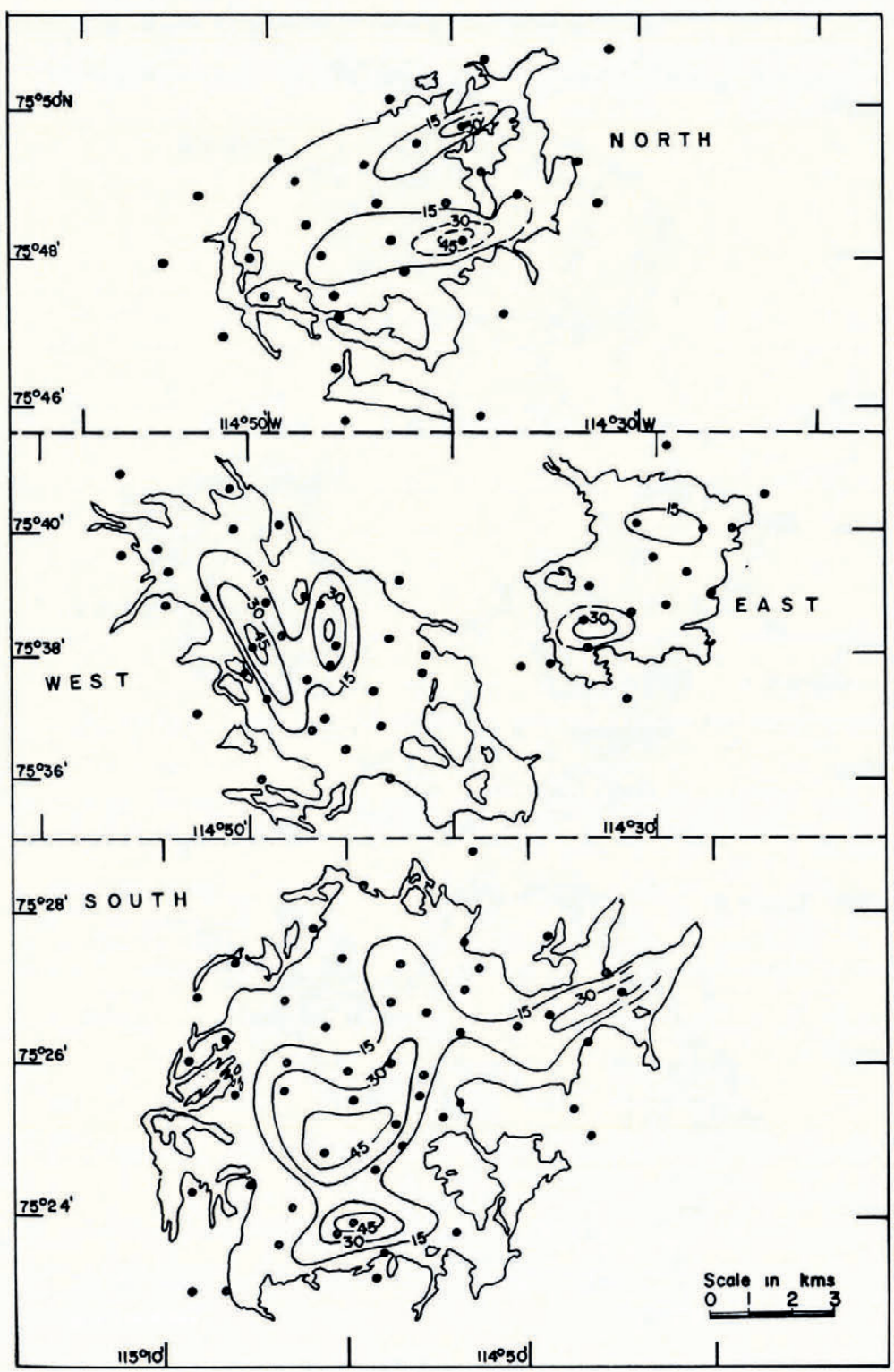

Fig. 4. Ice thickness maps as interpreted from gravity data, contour interval $I_{5} \mathrm{~m}$.

\section{ERRORS IN INTERPRETATION}

The presence of a number of important factors serves to limit the accuracy or uncertainty of ice thickness interpretation from gravity data. This is best demonstrated by considering the interpretation formula

$$
t=\frac{\Delta g}{2 \pi G \Delta \rho}
$$


The uncertainty in the value of the residual anomaly $\Delta g$ arises from the following considerations:

(a) reading error, uncorrected temperature drift in the gravity meter mechanism and uncorrected earth tide effect; \pm 0.05 mgal (estimated).

(b) positioning inaccuracy; \pm 0.05 minute of latitude; \pm 0.06 mgal.

(c) inaccuracy in trigonometric levelling; $\pm 0 \cdot 06 \mathrm{mgal}$.

(d) probable uncorrected terrain effect; $\pm 0 \cdot$ Io mgal (estimated).

(e) probable uncertainty in regional anomaly estimation; $\pm 0 \cdot$ Io mgal (estimated).

The total uncertainty in the $\Delta g$-factor is about $\pm 0 \cdot 40$ mgal. The uncertainty in the icebedrock density contrast is $\pm 0 \cdot 06 \mathrm{~g}$. $/ \mathrm{cm} .{ }^{3}$. Thus from the above formula

$$
t \pm \Delta t=\frac{\Delta g}{2 \pi G \Delta \rho}\left[\frac{\mathrm{I} \pm 0 \cdot 4 \mathrm{o} / \Delta g}{\mathrm{I} \pm 0 \cdot 06 / \Delta \rho}\right]
$$

or $\Delta t= \pm(7 \cdot 2+0 \cdot 7 \Delta g) \mathrm{m}$. with the aid of the Binomial Theorem. Hence for an anomaly of $2 \mathrm{mgal}$ the uncertainty or accuracy of ice thickness interpretation is

$$
\Delta t= \pm 8 \cdot 5 \mathrm{~m}
$$

Because of the large separation of gravity stations which results in a smoothed representation of the actual gravity field, interpretation of ice thicknesses are conservative. A more detailed survey especially across the thick ice zones coupled with interpretational techniques using more realistic models other than the slab approach may show that greatest ice thicknesses are considerably larger than have been estimated.

\section{Discussion}

Some of the main features of the Melville Island ice caps study are that the survey was made in an area in which the regional gravity is small due to the uniform geology of the area and that adequate topographic mapping had been done of the surrounding terrain, facilitating correction for terrain effect. An informative picture of the ice bodies results from the gravity interpretation regarding the nature of the ice-bedrock interface topography, the distribution of ice thickness and ice-cap volume.

MS. received 24 December 1965

\section{REFERENCES}

Bull, C., and Hardy J. R. 1956. The determination of the thickness of a glacier from measurements of the value of gravity. Journal of Glaciology, Vol. 2, No. 20, p. 755-63.

Dobrin, M. B. 1960. Introduction to geophysical prospecting. Second edition. New York, McGraw-Hill.

Hammer, S. 1939. Terrain corrections for gravimeter stations. Geophysics, Vol. 4, No. 3, p. 184-94.

Hammer, S. 1945. Estimating ore masses in gravity prospecting. Geophysics, Vol. 10, No. 1, p. $50-62$.

Koerner, R. M., and others. I 963 . The Devon Island Expedition, I $960-64$, by R. M. Koerner, A. Gill, S. Apollonio, J. P. Greenhouse, [and] R. D. Hyndman. Arctic, Vol. 16, No. I, p. 57-76.

Littlewood, C. A. 1952. Gravity measurements on the Barnes icecap, Baffin Island. Arctic, Vol. 5, No. 2, p. I $18-24$.

Russell, R. D., and others. 1960. Gravity measurements on the Salmon Glacier and adjoining snow field, British Columbia, Canada, by R. D. Russell, J. A. Jacobs and F. S. Grant. Bulletin of the Geological Society of America, Vol. 71, No. 8, p. 1223-29.

Spector, A. Unpublished. Crustal structure of the western Queen Elizabeth Islands. [M.A. thesis, University of Toronto, 1964.]

Thiel, E., and others. 1957. The thickness of Lemon Greek Glacier, Alaska, as determined by gravity measurements, by E. Thiel, E. [R.] LaChapelle and J. [C.] Behrendt. Transactions. American Geophysical Union, Vol. 38, No. 5, p. $745-49$. 
Thorsteinsson, R., and Tozer, E. T. 1959. Western Queen Elizabeth Islands, District of Franklin, N.W.T. Canada. Geological Survey. Paper 59-1.

Weber, J. R. 1961. Comparison of gravitational and seismic depth determinations on the Gilman Glacier and adjoining ice-cap in northern Ellesmere Island. (In Raasch, G.O., ed. Geology of the Arctic: proceedings of the first international symposium on Arctic geology held in Calgary, Alberta, fanuary $11-13,1960$. Toronto, University of Toronto Press, Vol. 2, p. 781-9o.) 